\title{
A COMPARATIVE STUDY BETWEEN THE USE OF REBOILERS AND DIRECT STEAM INJECTION IN DISTILLATION COLUMNS
}

\author{
R.O. da Silva ${ }^{1}$, R.O. Defendi ${ }^{1}$, L.M.M. Jorge ${ }^{1}$, V.C. Tiski ${ }^{1}$, O.C. Motta Lima ${ }^{1}$ \\ ${ }^{1}$ State University of Maringa, Chemical Engineering Department \\ E-mail: orgeda@hotmail.com
}

\begin{abstract}
Ethanol can be obtained by the distillation process. Once there are doubts about the advantages and disadvantages of direct and indirect heating, the aim of this work was to compare three alcohol distillation column projects, using direct steam injection, partial and total reboiler to heat the column. Results based on the case studied showed it is possible to have a stillage quantity reduction of almost $17 \%$ and $1.8 \%$ of the steam with the use of partial or total reboiler. Based on the quantity of steam decrease observed, it was possible to estimate the payback time of approximately two years for both types of reboilers. Therefore, the partial reboiler proved to be more viable than the total one, since it promotes a separation stage, which can increase the column efficiency and also there is a lower cost than the total reboiler in areas larger than $11,118.57 \mathrm{ft}^{2}$. It can be stated, in both financial and environmental aspects, that it is advantageous to carry out the replacement of direct steam injection with use of reboiler.
\end{abstract}

\section{INTRODUCTION}

Sugarcane processing is one of the most important industries in the Brazilian economy, mainly due to its competitiveness (Ensinas et al., 2009). This important segment has been increasing substantially every year, which propels the sugarcane harvest. According to recent researches related to distillation processes in an ethanol plant, the 2013/2014 production is predicted as 27.17 billion of liters, being 14.94\% higher than 2012/2013 production (CONAB, 2013).

The ethanol production process in a distillery is complex and involves the following unit operations, in this respective order: evaporation, fermentation, and distillation (Jorge et al., 2010). In order to produce ethanol, distillation processes deserve special attention because it is the final separation process of ethanol from the other components. Moreover, the ethanol industry in Brazil, which produces this fuel from sugarcane on a large scale for many years, is well known by its low energy (Dias et al, 2010). Therefore, there is still a huge field to be explored, mainly related to process improvement, energy integration and energy cogeneration.

Stillage, bottom product from distillation process, is rich in minerals and can be used as a by-product for agriculture. It is commonly used to irrigate sugarcane plantation, but it is also an environment pollutant (Silva et al., 2006; Marquini et al., 2007). Recent studies (Cruz et al., 2008) indicate that large quantities of stillage can generate problems such as: groundwater contamination when it is near the surface; logistical problems when sugarcane plantations are in distant places; 
and changes in the ground quality when stillage is applied in excess leading to saturation of some nutrients.

One of the ways to decrease the quantity of stillage is replacing the direct steam injection with a reboiler. The adequate operation of the reboiler is totally important for an effective distillation (PERRY, 1984). Therefore, the aim of this work was compare, technically and economically, three projects of distillation columns using direct steam injection, partial or total reboiler to heat the column.

\section{METHODOLOGY}

\subsection{Energy and Material Balances for Distillation Columns with Direct Steam Injection and Using Reboilers}

In the case of direct steam injection, there are two entering flows: the feed flow $\mathrm{F}(\mathrm{Kg} / \mathrm{h})$ with ethanol mass fraction $\mathrm{x}_{\mathrm{F}}$ and the steam flow $\mathrm{W}(\mathrm{Kg} / \mathrm{h})$. Simultaneously, two other flows leave the system: the top product flow $V_{1}(\mathrm{Kg} / \mathrm{h})$, with ethanol mass fraction $\mathrm{y}_{1}$ and the bottom product flow $\mathrm{B}(\mathrm{Kg} / \mathrm{h})$, with ethanol mass fraction $\mathrm{x}_{\mathrm{B}}$. Global material and thermal balances were arranged assuming an adiabatic column. Therefore, it reached the following linear system of equations:

$$
\begin{aligned}
& V_{1}+B-W=F \\
& V_{1} \cdot y_{1}+B \cdot x_{B}-W \cdot y_{W}=F \cdot x_{F} \\
& V_{1} \cdot H_{1}+B \cdot h_{B}-W \cdot H_{W}=F \cdot h_{F}
\end{aligned}
$$

Solving the equation system above, with three equations and three variables, were found values for $\mathrm{V}_{1}$, B e W. Thermal and material balances using reboiler were arranged to obtain the following linear system equations:

$$
\begin{aligned}
& V_{1}+B=F \\
& V_{1} \cdot y_{1}+B \cdot x_{B}=F \cdot x_{F}
\end{aligned}
$$

Considering an adiabatic stripping column, its thermal balance will consist as the equality between the sum of the quantity of entering energy plus the quantity of heat exchanged in the reboiler, being $F . h_{F}$ and $q_{r}$, respectively, minus the sum of the energy of exiting flows, $V_{1} \cdot H_{1}$ and B. $h_{B}$. Isolating $q_{r}$, it reached the following equation:

$$
q_{r}=V_{1} \cdot H_{1}+B \cdot h_{B}-F \cdot h_{F}
$$

A new value of steam flow rate used by reboiler was found to carry out the same process when the direct steam injection was used dividing $\mathrm{q}_{\mathrm{r}}$ by latent heat of vaporization $\lambda$.

$$
w=q_{r} / \lambda
$$

\subsection{Number of Plates Calculation}


The McCabe-Thiele method has used in order to find the number of plates of distillation columns with direct steam injection and using reboiler. This method has showed appropriate to estimate the number of plates in the studied case, as the temperature difference between the top and bottom was about $10^{\circ} \mathrm{C}$.

\subsection{Design of Reboiler}

The heat exchange external area of the reboiler $A_{r}$ was designed according to the equation proposed by Kern (1982) and represented by the Equation 8.

$$
A_{r}=\frac{q_{r}}{U . L M T D}
$$

The value of $\mathrm{q}_{\mathrm{r}}$ was calculated by Equation 7. The value of overall heat transfer coefficient U was obtained from (COPPETI, 2013), which represents the ranges of overall heat transfer coefficient depending on the refrigerating fluids. The $\log$ mean temperature difference of evaporator LMTD was calculated from the log mean between the hot terminal temperature (stillage outlet and steam inlet) and cold terminal temperature (stillage inlet and condensate outlet) of the reboiler.

\subsection{Cost Analyze}

The cost analyze was based on the comparison of the value of tons of steam used in the direct steam injection case with the new value of steam flow used by the reboiler case, plus the price of heat exchange acquisition.

The price of tons of steam was measured by Evaristo (2008) in his master's thesis in which it is presented stochastically the results of the simulation model of an average cost management system of saturated steam, produced by boiler, in the agroindustry. The price of reboiler project was determined by a relation proposed by Milligan (2012), which gave this cost based on parameters as heat exchange external area, internal pressure, material composition, and the type of reboiler (partial and total). Finally, the required period of time for the return on an investment to pay the sum of the original investment was determined and then calculated the payback time.

\subsection{Field Research}

A field research was carried out in an industrial plant in operation which produces hydrated ethanol and where the substitution proposed in this article has already done. Data and information collected in this plant were used to design the reboiler and also to support realistically the discussion of advantages and disadvantages of the project of the substitution from direct steam injection to reboilers in a stripping column.

\section{CASE STUDY}

To perform this comparative analysis, the case proposed by Marquini (2007) was considered. Firstly, inlet and outlet flow parameters of the stripping column (column A) as well as their ethanol mass fraction were used, as shown in Figure 1. This case study was based just on the stripping column. 


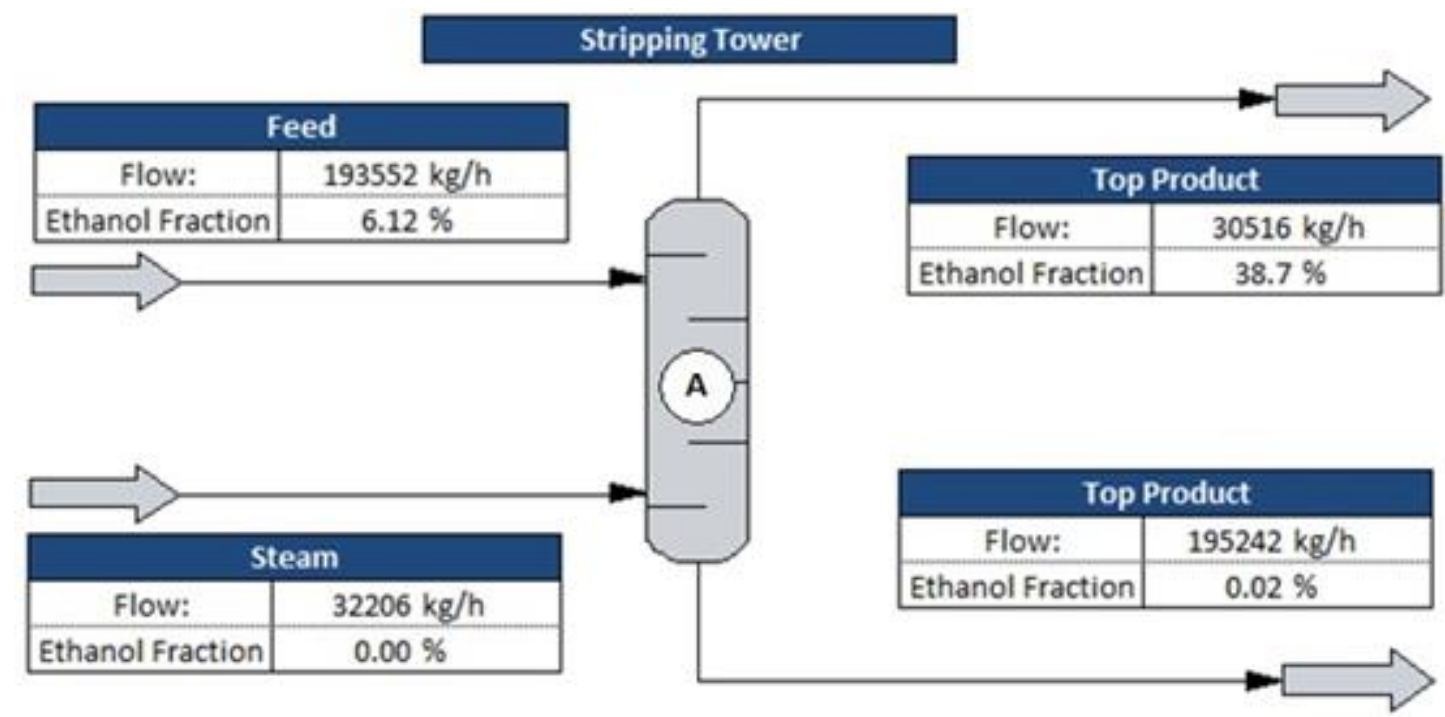

Figure 1 - Case of distillation column with direct steam injection used as a base to compare with the use of reboilers (Marquini, 2007).

Mass fractions of the flows, presented in ethanol-water equilibrium diagram, were converted to molar fractions. It was considered the vapor injected in the distillation column free of ethanol. Results of molar fractions are $\mathrm{x}_{\mathrm{F}}=0.025, \mathrm{y}_{1}=0.20, \mathrm{x}_{\mathrm{B}}=7.82 \times 10^{-5}$ and $\mathrm{y}_{\mathrm{w}}=0.00$.

\subsection{Results From Balances}

The first step of this case study was to do the comparison between real values from stripping column analyzed and values generated by the system of equations evaluating the same parameters. Table 1 shows the flow values of feed (F), top product (V1), bottom product and the steam (W), for both mentioned cases and the percentage error between them.

Table 1 - Comparison between real values of the case study and calculated values proposed.

\begin{tabular}{cccc}
\hline Parameters & $\begin{array}{c}\text { Real values } \\
\left(\mathbf{K g}_{\mathbf{h}} \mathbf{- 1}^{\mathbf{1}}\right)\end{array}$ & $\begin{array}{c}\text { Calculated values } \\
\left(\mathbf{K g}^{-\mathbf{1}} \mathbf{)}\right.\end{array}$ & $\begin{array}{c}\text { Percentage Error } \\
(\boldsymbol{\%})\end{array}$ \\
\hline $\boldsymbol{V}_{\boldsymbol{l}}$ & 30516,00 & 30510,69 & 0,017 \\
$\boldsymbol{B}$ & 195242,00 & 196305,30 & 0,54 \\
$\boldsymbol{W}$ & 32206,00 & 33263,23 & 3,28 \\
$\boldsymbol{F}$ & $193.552,00$ & 193552,00 & 0,00 \\
\hline
\end{tabular}

As $3.28 \%$ was the highest percentage error among values found by the system of equations, it was possible to say that those values were found close to the real values obtained from the case study. It indicates the validation of considered equations system based on mass and energy balances developed at item 2.1 .

The quantity of heat required heating up the reboiler and exchanges heat with the stillage was obtained by equation 6 . From this information, it was possible to estimate the new steam flow to be used by the reboiler. A safety range of $10^{\circ} \mathrm{C}$ difference of temperature between the inlet of stillage temperature and inlet steam temperature in the reboiler was considered. 
The temperature of stillage inlet (liquid) and outlet (gas) in the reboiler were $112{ }^{\circ} \mathrm{C}$. The temperature of the steam inlet (gas) and the condensate outlet (liquid) were $122{ }^{\circ} \mathrm{C}$. Specific enthalpy of vaporization at $122{ }^{\circ} \mathrm{C}(\lambda)$ was $2,081.48 \mathrm{Btu} \cdot \mathrm{Kg}^{-1}$. The heat exchange area was calculated varying the overall heat transfer coefficient value from $1,000 \mathrm{~W} / \mathrm{m}^{2} \mathrm{~K}$ to $3,500 \mathrm{~W} / \mathrm{m}^{2} \mathrm{~K}$, with an increment of $100 \mathrm{~W} / \mathrm{m}^{2} \mathrm{~K}$.

Based on the low error percentage shown in the Table 1, it was possible to compare the results of the direct steam injection case with the system used to heat the column when the direct steam injection is replaced with reboiler.

Table 2 Comparison between direct steam injection and the use of reboiler.

\begin{tabular}{cccc}
\hline Parameter & $\begin{array}{c}\text { Balance } \\
\left(\mathbf{K g . h}^{-\mathbf{1}}\right)\end{array}$ & $\begin{array}{c}\text { Reboiler } \\
\left(\mathbf{K g . h}^{-\mathbf{1}}\right)\end{array}$ & Variation (\%) \\
\hline $\boldsymbol{V}_{\boldsymbol{I}}$ & $30,510.69$ & $30,523.97$ & 0.043 \\
$\boldsymbol{B}$ & $196,305.30$ & $163,028.03$ & 16.95 \\
$\boldsymbol{W}$ & $33,263.23$ & $32,669.93$ & 1.78 \\
$\boldsymbol{F}$ & $193,552.00$ & $193,552.00$ & 0.00 \\
\hline
\end{tabular}

This comparison showed, mainly, the variation of stillage quantity between both cases. It was possible to estimate the reduction of $16.95 \%$ of stillage quantity. Moreover, it was also estimated a reduction of $1.78 \%$ of steam quantity used when the reboiler, both partial and total reboiler, is replaced by direct steam injection.

\subsection{Number of Plates}

According to McCabe (2001), the graphic method shows the use of reboiler tends to reduce the number of plates of a distillation column when compared with direct steam injection case. However, in this studied case, the value of molar fraction of bottom product is too low $\left(\mathrm{x}_{\mathrm{B}}=\right.$ $7.82 \times 10^{-5}$ ), that is, close to zero. It means the number of the plates practically will not vary when the process using direct steam injection system to heat the column is replaced with a reboiler.

\subsection{Cost Analysis}

The cost analysis was performed from the reboiler thermal exchange area varying the overall heat transfer coefficient summed to information obtained through the field research. The field research exposed that the maximum internal pressure of work is normally $35.56 \mathrm{psi}\left(2.5 \mathrm{Kgf} / \mathrm{cm}^{2}\right)$, so the value of 150 psi was chosen because it was the closest value presented at Milligan (2003) electronic page to budget prices of partial and total reboilers. The field research also revealed that the material which composed the reboiler used in this observed plant in operation was carbon steel. For this reason, this same material was used to budget the reboilers. The Figure 2 shows the relation between the area and price of the total and partial reboiler.

The Figure 2 indicates that there is a moment in the overall heat transfer coefficient range, from $1.000 \mathrm{~W} / \mathrm{m}^{2} \mathrm{~K}$ to $3.500 \mathrm{~W} / \mathrm{m}^{2} \mathrm{~K}$, in which the prices of both reboilers are equivalent. The price and area found by extrapolation of both trend lines, linear and power respectively, which is the equivalent point, are $\mathrm{R} \$ 361.316,74$ and $11.118,57 \mathrm{ft}^{2}$. 
It was possible to make an estimative of steam savings, since the set steam price, proposed by Evaristo and Figueiredo (2008), which is $0,04 \mathrm{Kg} / \mathrm{h}$, based on the reduction of $593,27 \mathrm{Kg} / \mathrm{h}$ of steam flow when the direct injection is replaced with a reboiler. It reached a monthly cost of steam savings of $\mathrm{R} \$ 17.087,07$. Therefore, it was possible to obtain enough data to calculate the payback time. Using equation 11 it resulted in 20.52 months for partial reboiler and 20.72 months for total reboiler

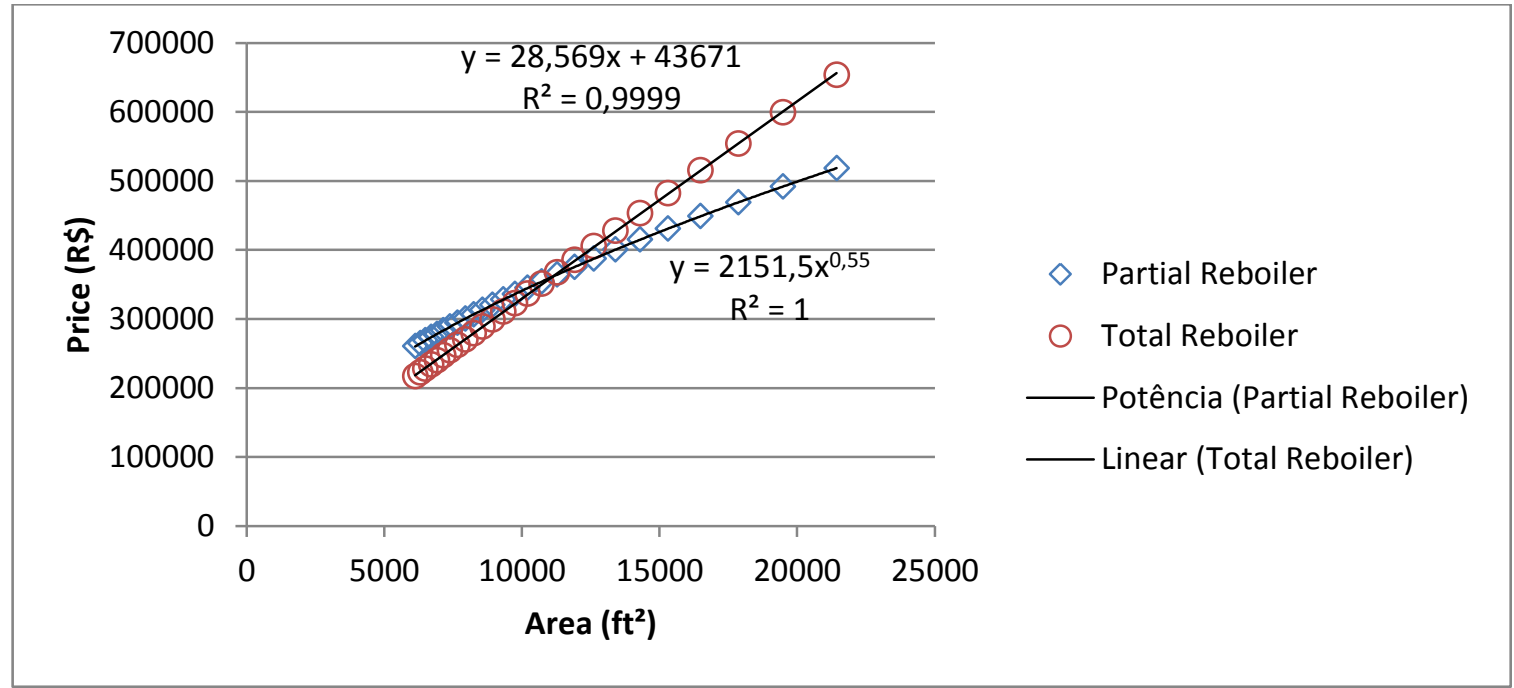

Figure 2 - Comparison of the relation between heat exchange area and prices of the reboilers, with a linearization of total reboiler and a power trend line of partial reboiler.

.The payback time for both reboilers has shown strongly similar. As discussed previously, the total reboiler price is less expensive when the considered heat exchange area is smaller than $11,118.57 \mathrm{ft}^{2}$. When the heat exchange area becomes higher than this equivalent value, the partial reboiler becomes financially more viable. Furthermore, the partial reboiler presents an advantage of performing as another separation stage, in other words, as another plate. This fact can increase the separation efficiency of the distillation column.

\section{CONCLUSIONS}

Based on the environmental issue, the aim of this study proved to be interesting. Once the quantity of stillage decrease tends to reduce their environmental impacts as well as costs of the company that needs to treat it appropriately before their discharge. On the other hand, focusing on the economic factor, replace the direct steam injection with the use of reboilers also proved financially viable by presenting a reduction of the quantity of steam used, approximately $1.8 \%$, and a payback time less than two years for both types of reboilers.

When using indirect heating, there is utilization of the condensate. When using the direct heating, steam used becomes liquefied, adding the stillage, increasing its volume and making the reuse of water from the steam impossible. 
If there is a real intention to carry out the replacement of direct heating with indirect, the partial reboiler showed doubly advantageous for larger areas than $11,118.57 \mathrm{ft}^{2}$, once it promotes another separation stage, increasing the tower efficiency, and it is cheaper than the total reboiler.

\section{REFERENCES}

CONAB. Acompanhamento de safra brasileira : cana-de-açúcar, segundo levantamento, agosto/2013 - Companhia Nacional de Abastecimento. - Brasília : Conab 2013., p. 10. <http://www.conab.gov.br/conteudos.php?a=1253\&t=2> (acessed 23.09.13).

COPPETI, J.B. Coeficiente global de transferência de calor. Unisinos. $<$ http://professor.unisinos.br/jcopetti/sisterm> (acessed 14.09.13).

CRUZ, J.I., Portugal, R.S., Lucendo, M.C., Elis, V.R., Fachini, S.J.S., Ustra, A.T. \& Borges, W.R. (2008). Detecção de contaminação de solo por vinhaça através de análise de dados de eletrorrestividade. Revista Brasileira de Geofísica 26, p. 481-492.

DIAS, M.O.S.; MODESTO, M.; ENSINAS, A.V.; NEBRA, S.A.; FILHO, R.M. \& ROSSEL, C.E.V. (2010). Improving bioethanol production from sugarcane: evaluation of distillation, thermal integration and cogeneration systems. Energy 36, p. 3691-3703.

ENSINAS, A.V.; MODESTO, M.; NEBRA, S.A. \& SERRA, L. (2009) . Reduction of irreversibility generation in sugar and ethanol production from sugarcane. Energy 34, p. 680-688.

EVARISTO, K.S. \& FIGUEIREDO, R.S. (2008). Custo do vapor na agroindústria. Dissertação (Mestrado). Universidade Federal de Goiás.

JORGE, L.M.M.; RIGHETTO, A.R.; POLLI, P.A.; SANTOS, O.A.A. \& FILHO, R.M. (2010). Simulation and analysis of a sugarcane juice evaporation system. Journal of Food Engineering 99, p. 351-359.

KERN, D. Q. (1982). Processos de transmissão de calor. Rio de Janeiro: Editora Guanabara Dois. p. 127-151.

MARQUINI, M.F.; MARIANI, D.C.; MEIRELLES, A.J.A.; SANTOS, O.A.A.S. \& JORGE, L.M.M. (2007). Análise de um sistema industrial de colunas de destilação. Acta Science Technology 29, p. 23-28.

MCCABE, W.L. (2001). Unit operations of chemical engineering. 6th ed. p. 641-651.

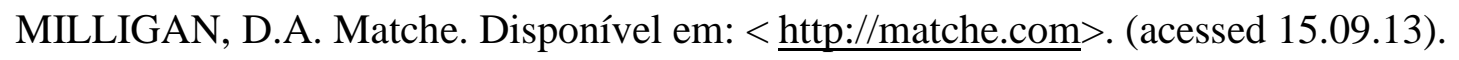

SILVA, M.A.S., GRIEBELER, N.P. \& BORGES, L.C. (2007). Uso de vinhaça e impactos nas propriedades do solo e lençol freático. Revista Brasileira de Engenharia Agrícola e Ambiental. p. 108-114. 